\title{
Semi-natural test methods to evaluate fire safety of wall claddings: Update
}

\author{
Miroslav Smolka ${ }^{1}$, Eleonora Anselmi ${ }^{2}$, Tony Crimi ${ }^{3}$, Bruce Le Madec ${ }^{1}$, István Ferenc Móder ${ }^{4}$, \\ Kye Won Park ${ }^{5}$, Roman Rupp ${ }^{1}$, Yong-Ho Yoo ${ }^{6}$ and Hideki Yoshioka ${ }^{7}$ \\ ${ }^{1}$ Rockwool International A/S, Denmark \\ ${ }^{2}$ L.S.Fire Testing Institute srl, Como, Italy \\ ${ }^{3}$ A.C. Consulting Solutions Inc., Canada \\ ${ }^{4}$ ÉMI Budapest, Hungary \\ ${ }^{5}$ Fire Insurers Laboratories of Korea \\ ${ }^{6}$ Korea Institute of Civil Eng. and Building Technology \\ ${ }^{7}$ National Institute for Land and Infrastructure, Japan
}

\section{INTRODUCTION}

There are a number of test methods worldwide to evaluate fire safety of facades. An overview of available test methods implemented in fire safety codes was presented at the $1^{\text {st }}$ Conference of Fire Safety of Facades in 2013. [1] Since then, a number of changes and developments occurred. The purpose of this paper is to present the updated global overview of facade fire spread test methods made for building regulations.

On top of that, work is going on developing new test methods or amending existing ones. The paper presents major developments and principles of revisions to existing standards.

\section{UPDATES ON NEW FAÇADE TEST METHODS AND REVISIONS}

\subsection{Germany: New test for façade base (bottom part/edge)}

An internal procedure of the German building institute (DIBT) [2] has been in use since 2015. Its purpose is to demonstrate the suitability of fire protection measures against a fire exposure from outside a building in the immediate vicinity of the facade ("base fire exposure") for External Thermal Composite Insulating Systems (ETICS) with polystyrene insulation.

The test wall is a reentrant corner 4 wide, $2 \mathrm{~m}$ deep, and $9.8 \mathrm{~m}$ high (minimum dimensions). Fire load is made up by a wood crib $200 \mathrm{~kg}$ in total. The test requires quite substantial instrumentation: more than 200 thermocouples placed inside the tested system, and $20 \mathrm{~mm}$ from its outer surface.

The test procedure does not contain a set of pass/fail criteria; test evaluation is reserved by the German building institute. The measured values and observations include temperatures, visible flame spread, falling parts, burning droplets, and any damage observed on the façade system after the test. The

This is an Open Access article distributed under the terms of the Creative Commons Attribution License 2.0, which permits unrestricted use, distribution, and reproduction in any medium, provided the original work is properly cited. 

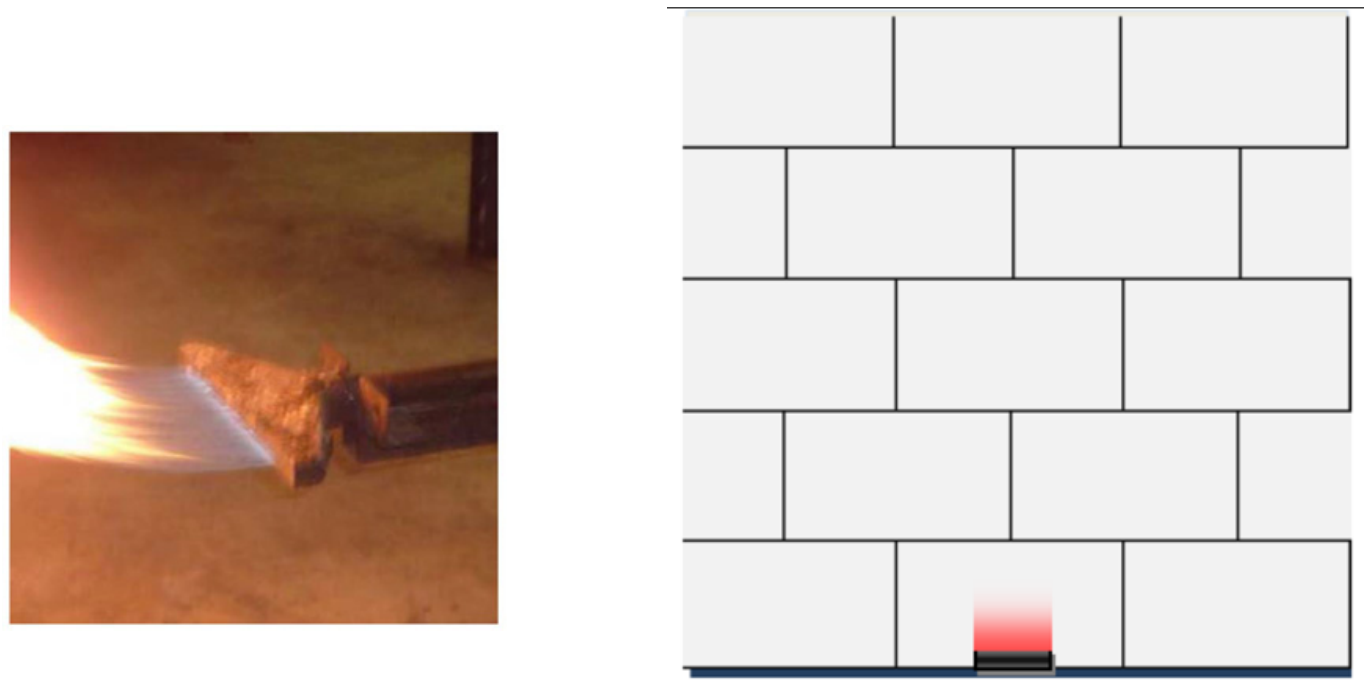

Figure 1. The $1^{\text {st }}$ (insulation material) test. Left: the burner. Right: test configuration. Author: Eleonora Anselmi.

only criteria mentioned as reasons to terminate the test prematurely (prior to 60 minutes into the test) is the flame reaching the top edge of the specimen or a safety threat to personnel.

Although the test is reportedly intended as an internal procedure for establishing safety levels and building regulations by authorities with a temporary applicability, the current occupation of laboratories performing this test suggest that this test method continues to be used on commercial basis.

The other German test method DIN E 4102-20 [3] is expected to be published as a full DIN standard in 2016.

\subsection{Japan: New façade fire test}

New test method was published as the Japanese industrial standard in 2015 as JIS A 1310: 2015 [4]. The test method has been developed on the basis of experiments presented in 2013 [5]. The method originated from ISO 13785-1:2002 [6] (the screening test accompanying the large-scale test ISO 13785-2 [7]. Similar to ISO13785-1, the new Japanese standard is intended as "a screening method for determining the fire propagation of products and constructions of a building façade when exposed to flames ejected from the opening" [4].

The method differentiates from ISO 13785-1 quite substantially, however. It lacks the lateral wing, and the fire load is $6 \mathrm{x}$ higher. Instead of a linear burner placed directly under the lintel or the bottom edge (base) of the façade system, it has a square burner placed inside the elevated combustion chamber, in order to avoid the situation where molten droplets from the burning façade specimen covers the top surface of linear burner.

The standard follows the pattern of ISO façade fire testing standards in focussing on the incident heat flux in the first place. Surface temperatures and temperatures $50 \mathrm{~mm}$ from the surface are measured as well. There is no measurement of internal temperature measurment inside insulation products, but observation of melting droplets and falling parts is recommended.

The method is not aimed at any particular product or construction technology; its scope are all types of facades even including those with ventilated air gaps.

Japan is currently looking at developing a classification system based on this standard. 

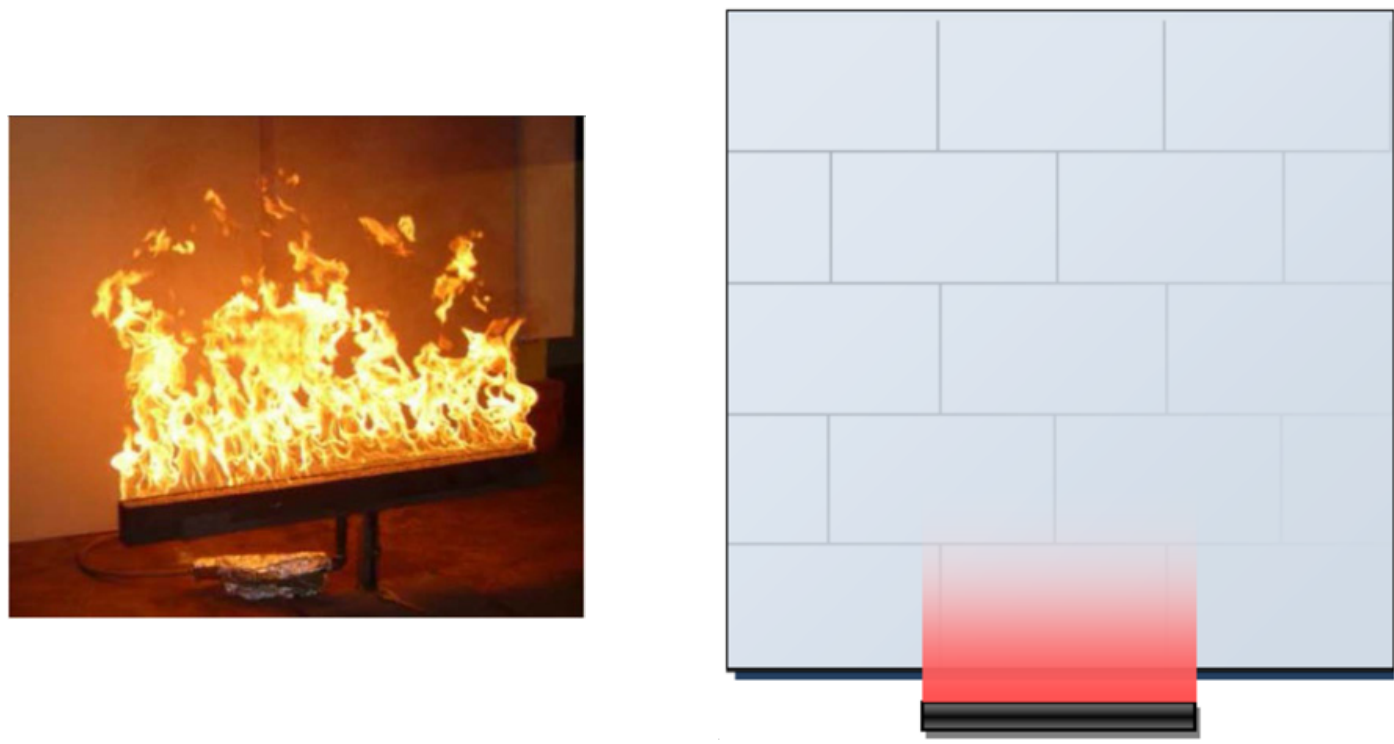

Figure 2. The $2^{\text {nd }}$ (ETICS system) test. Left: the burner. Right: test configuration. Author: Eleonora Anselmi.

\subsection{Italy: New façade fire tests using the Room Corner measuring equipment}

The Mistry of Interior has commissioned developing a relatively-low-cost method for evaluating fire safety of rendered façade systems [8]. The proposal has two parts:

- Construction work fire scenario: mounting face fire scenario in which only the uncoated insulation element of the system is exposed to an ignition source.

- Finished work fire scenario: fire scenario in which the ETICS system in its end use condition is exposed to an ignition source.

Both tests are carried out using the room corner ISO 9705 [9] equipment in order to measure the heat release rate and to compare it considering different insulation components.

For both tests, the size of the specimen is $2950 \mathrm{~mm} \times 2950 \mathrm{~mm}$. The damaged height (vertical flame spread) must not exceed $2.5 \mathrm{~m}$, and lateral flame spread must not reach the specimen edges; if the $1^{\text {st }}$ test passes it is possible to proceed with the $2^{\text {nd }}$ test.

The $1^{\text {st }}$ test is performed with the specimen consisting in the insulation product of its real thickness installed on the wall without the top covering layers (render).

In Italy, majority of fire accidents occurred in the construction site scenario, where the uncoated insulation element is exposed directly to the fire; the main ignition sources are uncontrolled use of the flame during the application of the bituminous sheathing. As a result, the test is carried out with a ribbon-type propane gas-burner that reaches $30 \mathrm{~kW}$ [8].

Total heat release, rate of heat release, and smoke optical density are also measured and reported. The specimen of the $2^{\text {nd }}$ test consists of the finished ETICS system but looks at the same measured values and criteria; the main differences are:

- The power of the burner that reaches $300 \mathrm{~kW}$.

- The type of the burner (linear spreading burner) and its position (under the bottom edge of the test specimen, $50 \%$ deep).

- The fact that the ignition of the specimen due to burning droplets is not evaluated. 


\section{MATEC Web of Conferences}

In its current version, the test scope and test procedure description claim that it is only the system base that is subjected to examination. In fact, in Italy, the historical fire events occurred in such a scenario i.e. with a ETICS system protected on its surface by a glass fiber mesh and cement-based mortar because of ignition sources like burning garbage bins adjacent to the walls of the building or burning cars parked along its external perimeter. The test carried out on this scenario thus required a much more powerful fire model than the fire model used for the construction work fire scenario [8].

The burner power and position are based on the assumption that they represent the window-plume attack fire scenario as well.

\subsection{EOTA: Draft test procedures TR073}

A task group within the European Organisation for Technical Assessments (EOTA) has been drafting TR073 [9], a document containing 2 different test methods which are very similar to DIN E 410220 [3] and BS 8414-1 [10]. The two test methods described therein follow the usual test setup of reentrant corner and a combustion chamber. The test methodologies do not address incident heat flux but otherwise follow the usual pattern of temperature measurements and observations of the tested facade performance.

\subsection{CEN: New draft test method for cavity barriers}

One of the European routes to dealing with fire safety of wall claddings is testing fire performance of cavity barriers [11]. The new test method designated prEN 1364-6 [12] actually deals with all the applications where hidden fire spread is a safety risk: "Cavity barriers are provided within buildings to restrict the spread of smoke and fire in concealed spaces. Cavity barriers may be "closed" e.g. in roof voids, under raised floors, between the inner and outer leaves of walls such as in timber framed construction; or they may be "open" e.g. as used in ventilated facade systems, roof eaves, rain screen cladding systems etc." [12]

The test proposed is an indicative or benchmark test carried out in fire resistance furnace utilising the standard temperature/time curve. The cavity barrier under examination is installed within an artificial cavity made of aerated concrete, built on the fire resistance furnace ceiling. The test is looking at performance of the barrier in terms of integrity (i.e. flame penetration through the barrier) or insulation (maximum temperature above the barrier). The test is intended to be evaluated to European fire resistance criteria.

As it is obvious from the test description, the test method cannot replace a façade fire spread test; it can be used to complement such a test so that the large-scale façade test does not have to be repeated every time when a cavity barrier is replaced for an alternative product. The purpose of the test fits well in the European concept of Extended Application of Test Results (EXAP) where it can be used in conjunction with a future European façade spread test.

\subsection{ISO: Proposal for ISO 13785-2 revision}

ISO 13785-2 [7] was developed in ISO TC92 as a combination of large-scale facade tests available in 1990's and experience available at that time. Since then, significant experience has been gathered using the method as well as similar test methods worldwide. The need for revising ISO 13785-2 is obvious, and in particular concerns the following elements:

- Fire load and its calibration: the 3 types of fire load allowed need to be equalized;

- Heat flux measurement: plate thermometer can successfully replace heat-flux meters;

- Testing construction details of the tested facade system. 
To serve the current and future needs, attention could also be given to the following areas:

- Measurements and observations, including new items like falling parts and continuous smouldering;

- Presentation of results so that they are compatible with most used regulatory requirements;

- Use of the method for Fire Safety Engineering;

- Relation of the method with the intermediate-scale screening method ISO 13785-1 [6] which can be used as an approval test for specific areas of use.

ISO 13785-2 test facilities exist in Korea, Japan, Czech Republic, Poland. ISO 13785-1 and/or -2 are referred to in regulations of Czech republic and Korea, and have been used on voluntary basis in Poland and Slovakia; Australia and China are considering using the standard. The test method itself has recently been subjected to research $[13,14]$.

\subsection{USA: NFPA 285 revision}

The test method, which today is titled NFPA 285 [15], has been applied nationally in the US via adoption in the model building codes, and has resulted in an existing building stock with exterior walls that are more resistant to self-propagating fires. The NFPA 285 Standard is currently in its revision cycle. A new edition will be published in 2016. Several proposed changes have been considered, the most important of which is a revision to require at least one horizontal joint or seam to be located between $1 \mathrm{ft}(305 \mathrm{~mm})$ and $2 \mathrm{ft}(610 \mathrm{~mm})$ above the top of the window opening, and at least one vertical joint or seam upward from the center of the window opening. Combustible cladding materials and systems that have been tested together to show code compliance, such as various insulation or barrier materials, without joint/seams located as defined would also require each existing NFPA 285 test to show compliance with the new protocol.

\subsection{France: LEPIR II revision}

The test Lepir II [16] has been used in France since 1970’s and improved ever since. The current set of measured values and observations is the most complete of all current façade fire spread test methods including visible flame spread, temperatures at different levels, droplets, falling parts, and observation of glowing and smouldering combustion after the test.

Since 2013, a revision of the test protocol is leading to a series of tests in order to justify the possible compliance of façade solutions with the French regulation.

\subsection{Hungary: MSZ 14800-6 revision}

A minor revision to MSZ 14800-6 [17] is under preparation. It includes the extension of the test duration from 45 minutes to 60 minutes, specification of falling parts in the normative text of the standard, and more precise specification of phenomena to be observed during the test including burning droplets, ignition due to falling droplets, smoke, high radiation-level etc.

The test remains unique among the façade fire spread test methods in that it requires a controlled combustion following the standard temperature/time curve in the combustion chamber, and opening of the standard glazed window $5 \mathrm{~min}$ into the test simulating a sudden impingement of flames onto the façade. 


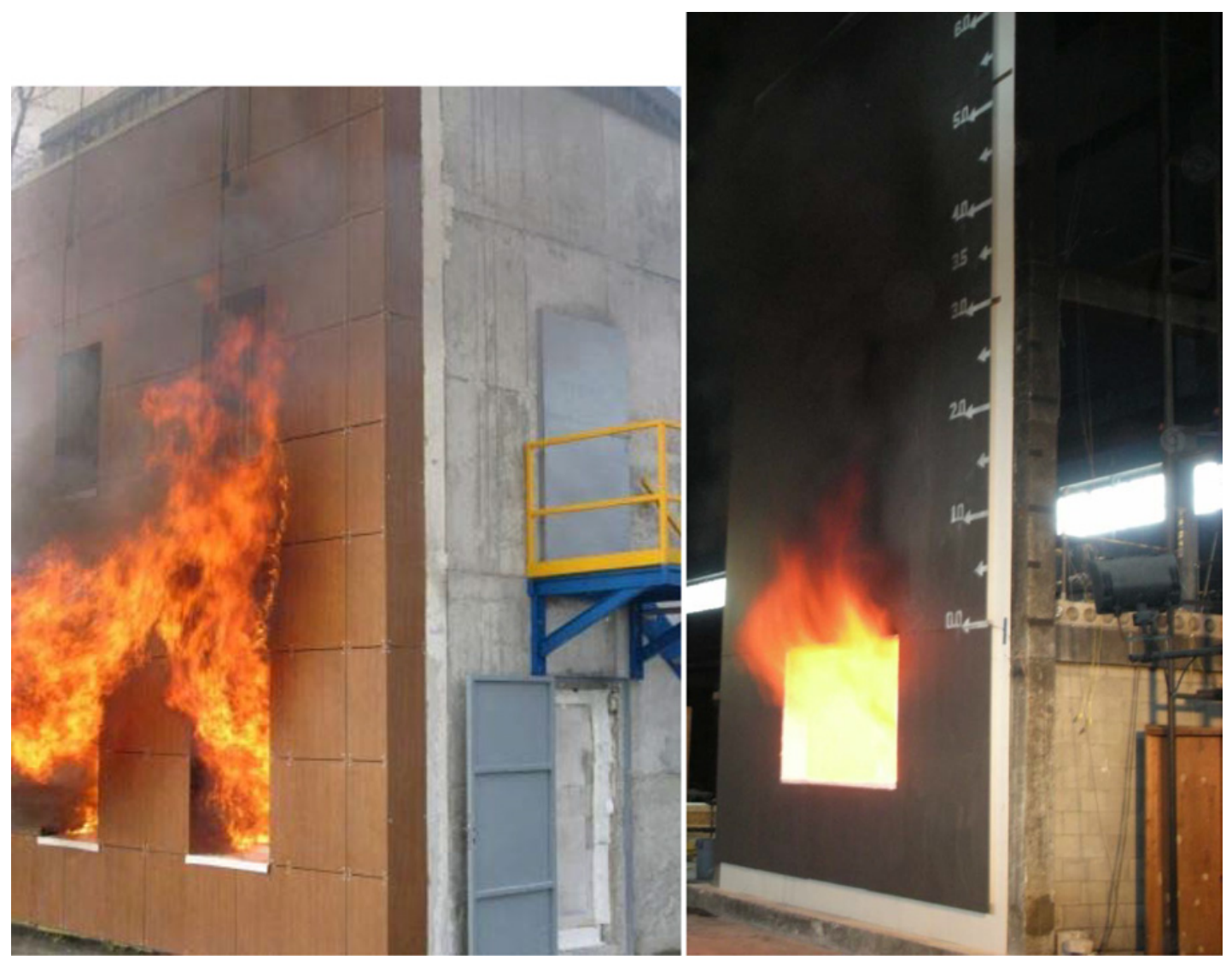

Figure 3. Large-scale façade tests. Left: Lepir II (France). Author: Bruce Le Madec. Right: CAN/ULC-S135 (Canada). Author: Tony Crimi.

\section{FAÇADE FIRE SPREAD TEST METHODS - EUROPEAN AND GLOBAL OVERVIEW}

Following are the updated table originally published in [1]. Apart from adding new test methods, minor additions and/or corrections were made.

\section{DISCUSSION AND CONCLUSION}

Due to the growing awareness about the importance of façade fire spread phenomenon supported by real fire cases, a number of countries has developed or revised their fire testing protocols. Despite attempts for harmonisation, the amount of diverse test methods is on the increase (even in European countries). The European Commission has started its own initiative to harmonise the methodology and classification of façade fire spread; the topic has drawn attention of both member states and industry. The obvious end result of such an initiative should be a harmonised system of façade fire performance testing and classification, based on a test that reflects real safety risks. There is no reason why such initiatives should be limited to different parts of the world when the problem of façade fire performance and its evaluation is truly global. 
$2^{\text {nd }}$ International Seminar for Fire Safety of Facades, Lund (Sweden), 2016

Table 1. Main parameters of major international and national test methods for fire spread on external wall cladding. Published standards and technical documents in Europe.

\begin{tabular}{|c|c|c|c|c|c|c|}
\hline Standard & BS 8414-1 & LEPIR II & MSZ 14800-6 & $\begin{array}{l}\text { SP FIRE } \\
105\end{array}$ & $\begin{array}{l}\text { Önorm B } \\
\mathbf{3 8 0 0 - 5}\end{array}$ & $\begin{array}{l}\text { PN-90/ } \\
\text { B-02867 }\end{array}$ \\
\hline Country & UK & $\mathrm{F}$ & $\mathrm{H}$ & $\mathrm{S}, \mathrm{DK}$ & A & PL \\
\hline $\begin{array}{l}\text { Fire } \\
\text { exposure }\end{array}$ & $\begin{array}{l}\text { Wood crib, } \\
\text { peak heat } \\
3.5 \mathrm{MW} \text {, } \\
4500 \mathrm{MJ}\end{array}$ & $\begin{array}{l}600 \mathrm{~kg} \\
\text { wood crib }\end{array}$ & $\begin{array}{l}650 \mathrm{~kg} \text { wood } \\
\text { crib, } 3 \mathrm{MW} \\
\text { approx. } \\
\text { (controlled) }\end{array}$ & $\begin{array}{l}601 \\
\text { heptane }\end{array}$ & $\begin{array}{l}25 \mathrm{~kg} \text { wood / } \\
320 \mathrm{~kW} \\
\text { propane }\end{array}$ & $\begin{array}{l}20 \mathrm{~kg} \text { wood } \\
\text { crib + wind } \\
\text { towards the } \\
\text { wall }(2 \mathrm{~m} / \mathrm{s})\end{array}$ \\
\hline $\begin{array}{l}\text { Max. heat } \\
\text { flux on } \\
\text { surface }\end{array}$ & $\begin{array}{l}70 \mathrm{~kW} / \mathrm{m}^{2} \text { at } \\
1 \mathrm{~m} \text { height }\end{array}$ & $\begin{array}{l}\text { Not } \\
\text { specified }\end{array}$ & $\begin{array}{l}\text { Not } \\
\text { specified }\end{array}$ & $\begin{array}{l}15 \text { or } \\
80 \mathrm{~kW} / \mathrm{m}^{2}\end{array}$ & $\begin{array}{l}\text { Not } \\
\text { specified }\end{array}$ & Not specified \\
\hline $\begin{array}{l}\text { Max. tem- } \\
\text { perature on } \\
\text { surface }\end{array}$ & $\begin{array}{l}600^{\circ} \mathrm{C} / \\
20 \mathrm{~min}\end{array}$ & $\begin{array}{l}\text { Average } \\
500^{\circ} \mathrm{C}, \\
\text { peak } \\
800^{\circ} \mathrm{C} \\
(\text { read at } \\
150 \mathrm{~mm} \\
\text { from the } \\
\text { surface) }\end{array}$ & $\begin{array}{l}600^{\circ} \mathrm{C} 0.5 \mathrm{~m} \\
\text { high / } \\
50 \mathrm{~min}\end{array}$ & $\begin{array}{l}450^{\circ} \mathrm{C} / \\
12 \mathrm{~min}\end{array}$ & $\begin{array}{l}\text { Not } \\
\text { specified }\end{array}$ & $800^{\circ} \mathrm{C}$ peak \\
\hline $\begin{array}{l}\text { Test } \\
\text { duration }\end{array}$ & $30 \mathrm{~min}$ & $\begin{array}{l}60 \mathrm{~min} \\
30 \mathrm{~min} \text { fire } \\
\text { exposure }\end{array}$ & $60 \mathrm{~min}$ & $\begin{array}{l}\text { Min. } 12 \\
\min \end{array}$ & $30 \mathrm{~min}$ & $30 \mathrm{~min}$ \\
\hline $\begin{array}{l}\text { Test } \\
\text { specimen }\end{array}$ & $\begin{array}{l}\text { Corner } \\
2.5 \mathrm{~m} \times 8.0 \mathrm{~m}+ \\
1.5 \mathrm{~m} \times 8.0 \mathrm{~m}\end{array}$ & $\begin{array}{l}\text { Flat wall } \\
5.0 \mathrm{~m} \times \\
6.6 \mathrm{~m}\end{array}$ & $\begin{array}{l}\text { Flat wall } \\
6.0 \mathrm{~m} \times 7.0 \mathrm{~m}\end{array}$ & $\begin{array}{l}\text { Flat wall } \\
4.0 \mathrm{~m} \times \\
6.7 \mathrm{~m}\end{array}$ & $\begin{array}{l}\text { Corner } 3.0 \mathrm{~m} \times \\
6.0 \mathrm{~m}+ \\
1.5 \mathrm{~m} \times 6.0 \mathrm{~m}\end{array}$ & $\begin{array}{l}\text { Flat wall } 2.3 \mathrm{~m} \\
\text { high }\end{array}$ \\
\hline Substrate & $\begin{array}{l}\text { Masonry or } \\
\text { light frame }\end{array}$ & Any & Masonry & $\begin{array}{l}\text { Aerated } \\
\text { concrete }\end{array}$ & $\begin{array}{l}\text { Aerated } \\
\text { concrete }\end{array}$ & Masonry \\
\hline Criteria $^{a}$ & Temp. limits & $\begin{array}{l}\text { Flame } \\
\text { spread, } \\
\text { system } \\
\text { integrity, } \\
\text { temp. rise, } \\
\text { falling } \\
\text { parts }\end{array}$ & $\begin{array}{l}\text { Temp. rise, } \\
\text { fire spread, } \\
\text { falling parts }^{b}\end{array}$ & $\begin{array}{l}\text { Flames } 2 \\
\text { floors } \\
\text { above; } \\
\text { Falling } \\
\text { parts }\end{array}$ & $\begin{array}{l}\text { Temp. rise, } \\
\text { fire spread, } \\
\text { falling parts }\end{array}$ & $\begin{array}{l}\text { Temp. limits; } \\
\text { Burning } \\
\text { particles }\end{array}$ \\
\hline
\end{tabular}

a) Additional criteria may be contained in other standards or regulations.

b) Temperature rise, vertical and/or horizontal flame spread, burning droplets and particles, falling parts of certain size or mass. 


\section{MATEC Web of Conferences}

Table 2. Main parameters of major international and national test methods for fire spread on external wall cladding. Draft standards and technical documents in Europe.

\begin{tabular}{|c|c|c|c|c|c|c|c|}
\hline Standard & $\begin{array}{l}\text { DIN E } \\
4102-20\end{array}$ & $\begin{array}{l}\text { DIBT } \\
\text { procedu } \\
\text { re }\end{array}$ & $\begin{array}{l}\text { Procedure } \\
\text { No. } 281- \\
\text { constructi } \\
\text { on phase }\end{array}$ & $\begin{array}{l}\text { Procedure } \\
\text { No. 281 - } \\
\text { finished } \\
\text { phase }\end{array}$ & $\begin{array}{l}\text { EOTA } \\
\text { draft } \\
\text { TR073 } \\
\text { Exp. 1 }\end{array}$ & $\begin{array}{l}\text { EOTA } \\
\text { draft } \\
\text { TR073 } \\
\text { Exp. 2 }\end{array}$ & $\begin{array}{l}\text { prEN } \\
1364-6\end{array}$ \\
\hline Country & $\mathrm{D}$ & $\mathrm{D}$ & I & I & EU & EU & EU \\
\hline $\begin{array}{l}\text { Fire } \\
\text { exposure }\end{array}$ & $\begin{array}{l}25 \mathrm{~kg} \\
\text { wood / } \\
320 \mathrm{~kW} \\
\text { propane }\end{array}$ & $\begin{array}{l}200 \mathrm{~kg} \\
\text { wood } \\
\text { crib }\end{array}$ & $\begin{array}{l}30 \mathrm{~kW} \\
\text { propane } \\
\text { burner }\end{array}$ & $\begin{array}{l}300 \mathrm{~kW} \\
\text { propane } \\
\text { burner }\end{array}$ & $\begin{array}{l}30 \mathrm{~kg} \\
\text { wood } \\
\text { crib }\end{array}$ & $\begin{array}{l}382.5 \mathrm{~kg} \\
\text { wood } \\
\text { crib }\end{array}$ & $\begin{array}{l}\text { Standard } \\
\text { temp./time } \\
\text { curve }\end{array}$ \\
\hline $\begin{array}{l}\text { Max. heat } \\
\text { flux on } \\
\text { surface }\end{array}$ & $\begin{array}{l}70-95 \mathrm{~kW} / \mathrm{m}^{2} \\
\text { at } 1 \mathrm{~m} \\
\text { height }\end{array}$ & $\begin{array}{l}\text { Not } \\
\text { specified }\end{array}$ & $55-60 \mathrm{~kW} / \mathrm{m}^{2}$ & $\begin{array}{l}\text { Not } \\
\text { specified }\end{array}$ & $\begin{array}{l}\text { Not } \\
\text { specified }\end{array}$ & $\begin{array}{l}\text { Not } \\
\text { specified }\end{array}$ & N/A \\
\hline $\begin{array}{l}\text { Max. tem- } \\
\text { perature on } \\
\text { surface }\end{array}$ & $\begin{array}{l}\text { Not } \\
\text { specified }\end{array}$ & $\begin{array}{l}\text { Not } \\
\text { specified }\end{array}$ & $\begin{array}{l}\text { Not } \\
\text { specified }\end{array}$ & $\begin{array}{l}\text { Not } \\
\text { specified }\end{array}$ & $\begin{array}{l}\text { Not } \\
\text { specified }\end{array}$ & $\begin{array}{l}\text { Not } \\
\text { specified }\end{array}$ & $\begin{array}{l}\text { Defined by } \\
\text { standard } \\
\text { temp./time } \\
\text { curve }\end{array}$ \\
\hline $\begin{array}{l}\text { Test } \\
\text { duration }\end{array}$ & $\begin{array}{l}21 \mathrm{~min} \\
\text { gas, } \\
30 \mathrm{~min} \\
\text { wood }\end{array}$ & $\begin{array}{l}60 \mathrm{~min} \\
25 \mathrm{~min} \\
\text { fire } \\
\text { exposure }\end{array}$ & $\begin{array}{l}15 \mathrm{~min} \\
10 \mathrm{~min} \text { fire } \\
\text { exposure }\end{array}$ & $\begin{array}{l}15 \mathrm{~min} \\
10 \mathrm{~min} \text { fire } \\
\text { exposure }\end{array}$ & $\begin{array}{l}60 \mathrm{~min} \\
30 \mathrm{~min} \\
\text { fire } \\
\text { exposure }\end{array}$ & $\begin{array}{l}60 \mathrm{~min} \\
30 \mathrm{~min} \\
\text { fire } \\
\text { exposure }\end{array}$ & $\begin{array}{l}\text { Customer } \\
\text { declaration }\end{array}$ \\
\hline $\begin{array}{l}\text { Test } \\
\text { specimen }\end{array}$ & $\begin{array}{l}\text { Corner } \\
3.0 \mathrm{~m} \times \\
5.2 \mathrm{~m}+ \\
2.0 \mathrm{~m} \times \\
5.2 \mathrm{~m}\end{array}$ & $\begin{array}{l}\text { Corner } \\
4 \mathrm{~m} \times \\
9.8 \mathrm{~m}+ \\
2 \mathrm{~m} \times \\
9.8 \mathrm{~m}\end{array}$ & $\begin{array}{l}3 \mathrm{~m} \times 3 \mathrm{~m} \\
\text { insulation } \\
\text { product } \\
\text { uncovered }\end{array}$ & $\begin{array}{l}3 \mathrm{~m} \times 3 \mathrm{~m} \\
\text { finished } \\
\text { ETICS } \\
\text { system }\end{array}$ & $\begin{array}{l}\text { Corner } \\
2.8 \mathrm{~m} \times \\
5.5 \mathrm{~m}+ \\
1.5 \mathrm{~m} \times \\
5.5 \mathrm{~m}\end{array}$ & $\begin{array}{l}\text { Corner } \\
2.8 \mathrm{~m} \times \\
9.0 \mathrm{~m}+ \\
1.5 \mathrm{~m} \times \\
9.0 \mathrm{~m}\end{array}$ & $\begin{array}{l}10 \times \\
\text { nominal } \\
\text { width of } \\
\text { cavity } \\
\text { barrier, } \\
\text { max } 3 \mathrm{~m}\end{array}$ \\
\hline Substrate & $\begin{array}{l}\text { Aerated } \\
\text { concrete }\end{array}$ & $\begin{array}{l}\text { Aerated } \\
\text { concrete }\end{array}$ & $\begin{array}{l}\text { According } \\
\text { to "end-use } \\
\text { condition" }\end{array}$ & $\begin{array}{l}\text { According } \\
\text { to "end-use } \\
\text { condition" }\end{array}$ & $\begin{array}{l}\text { Any } \\
\text { substrate }\end{array}$ & $\begin{array}{l}\text { Any } \\
\text { substrate }\end{array}$ & $\begin{array}{l}\text { Aerated } \\
\text { concrete }\end{array}$ \\
\hline Criteria $^{a}$ & $\begin{array}{l}\text { Temp. } \\
\text { rise, fire } \\
\text { spread, } \\
\text { falling } \\
\text { parts }^{\mathrm{b}}\end{array}$ & $\begin{array}{l}\text { Not } \\
\text { included }\end{array}$ & $\begin{array}{l}\text { height of } \\
\text { the } \\
\text { damaged } \\
\text { area } \\
<250 \mathrm{~cm} \text { and } \\
\text { not extending } \\
\text { to the } \\
\text { edges; } \\
\text { droplets } \\
\text { not } \\
\text { igniting the } \\
\text { specimen }\end{array}$ & $\begin{array}{l}\text { height of } \\
\text { the } \\
\text { damaged } \\
\text { area } \\
<250 \mathrm{~cm} \\
\text { and not } \\
\text { extending } \\
\text { to the } \\
\text { edges }\end{array}$ & $\begin{array}{l}\text { Temp. } \\
\text { rise, fire } \\
\text { spread, } \\
\text { falling } \\
\text { parts }^{\mathrm{b}}\end{array}$ & $\begin{array}{l}\text { Temp. } \\
\text { rise, fire } \\
\text { spread, } \\
\text { falling } \\
\text { parts }^{\mathrm{b}}\end{array}$ & $\begin{array}{l}\text { Integrity } \\
\text { and } \\
\text { insulation } \\
\text { (180 K max } \\
\text { temp. rise) }\end{array}$ \\
\hline
\end{tabular}

a) Additional criteria may be contained in other standards or regulations.

b) Temperature rise, vertical and/or horizontal flame spread, burning droplets and particles, falling parts of certain size or mass. 
$2^{\text {nd }}$ International Seminar for Fire Safety of Facades, Lund (Sweden), 2016

Table 3. Main parameters of major international and national test methods for fire spread on external wall cladding. International and Asian tests.

\begin{tabular}{|l|l|l|l|l|}
\hline Standard & ISO 13785-2 & ISO 13785-1 & GOST 31251 & JIS A 1310 \\
\hline Country & CZ, SK & CZ, SK & $\begin{array}{l}\text { AZ, AM, KG, KZ, MD, } \\
\text { RU, TJ, UZ, UA }\end{array}$ & JP \\
\hline $\begin{array}{l}\text { Fire } \\
\text { exposure }\end{array}$ & $\begin{array}{l}\text { Propane set by } \\
\text { calibration }\end{array}$ & $\begin{array}{l}\text { Propane } 100 \\
\mathrm{~kW}\end{array}$ & Soft wood $700 \mathrm{MJ} / \mathrm{m}^{2}$ & $\begin{array}{l}\text { Propane } 600 \mathrm{~kW} \text { or } \\
\text { more }\end{array}$ \\
\hline $\begin{array}{l}\text { Max. heat } \\
\text { flux on } \\
\text { surface }\end{array}$ & $\begin{array}{l}55 \mathrm{~kW} / \mathrm{m}^{2} \text { at } \\
0.6 \mathrm{~m} \text { height }\end{array}$ & Not specified & $\begin{array}{l}12.5 \mathrm{~kW} / \mathrm{m}^{2} \text { at } 2 \mathrm{~m} \\
\text { height }\end{array}$ & Not specified \\
\hline $\begin{array}{l}\text { Max. temp. } \\
\text { on surface }\end{array}$ & Min. $800^{\circ} \mathrm{C}$ & $\begin{array}{l}\text { Max. } 150^{\circ} \mathrm{C} \text { at } \\
0.5 \mathrm{~m} \text { height }\end{array}$ & $750^{\circ} \mathrm{C}$ at lintel & Not specified \\
\hline $\begin{array}{l}\text { Test } \\
\text { duration }\end{array}$ & $23-27 \mathrm{~min}$ & $30 \mathrm{~min}$ & $35 \mathrm{~min}$ & $\begin{array}{l}25 \text { min } \\
20 \text { min fire exposure }\end{array}$ \\
\hline $\begin{array}{l}\text { Test } \\
\text { specimen }\end{array}$ & $\begin{array}{l}\text { Corner } 3.0 \mathrm{~m} \times \\
5.7 \mathrm{~m}\end{array}$ & $\begin{array}{l}\text { Corner } 1.2 \mathrm{~m} \times \\
2.4 \mathrm{~m}+0.6 \mathrm{~m} \times \\
2.4 \mathrm{~m}\end{array}$ & Flat wall $3.0 \mathrm{~m} \times 5.1 \mathrm{~m}$ & Flat wall $1.8 \mathrm{~m} \times 4.1 \mathrm{~m}$ \\
\hline Substrate & Any & $\begin{array}{l}12 \mathrm{~mm} \text { Ca-Si } \\
\text { board }\end{array}$ & Masonry, concrete & $\begin{array}{l}\text { Two layers of } \\
12 \text { mm Ca-Si board }\end{array}$ \\
\hline Criteria
\end{tabular}

a) Additional criteria may be contained in other standards or regulations.

b) Temperature rise, vertical and horizontal flame spread.

Table 4. Main parameters of major international and national test methods for fire spread on external wall cladding. North American tests.

\begin{tabular}{|c|c|c|c|c|}
\hline Standard & NFPA 285 & NFPA 268 & CAN/ULC-S134 & $\begin{array}{l}\text { CAN/ULC-S101 + } \\
\text { CAN/ULC-S114 }\end{array}$ \\
\hline Country & USA & USA & CAN & CAN \\
\hline $\begin{array}{l}\text { Fire } \\
\text { exposure }\end{array}$ & Gas burner & $\begin{array}{l}\text { Radiant panel } \\
12.5 \mathrm{~kW} / \mathrm{m}^{2}\end{array}$ & $\begin{array}{l}\text { Propane set by } \\
\text { calibration }\end{array}$ & $\begin{array}{l}\text { Defined time/temp } \\
\text { curve }\end{array}$ \\
\hline $\begin{array}{l}\text { Max. heat } \\
\text { flux on } \\
\text { surface }\end{array}$ & $\begin{array}{l}38-40 \mathrm{~kW} / \mathrm{m}^{2} \text { at } \\
0.6-1.2 \mathrm{~m} \text { height }\end{array}$ & $12.5 \mathrm{~kW} / \mathrm{m}^{2}$ & $\begin{array}{l}45 \mathrm{~kW} / \mathrm{m}^{2} \text { at } 0.5 \mathrm{~m} \\
\text { height }\end{array}$ & Not specified \\
\hline $\begin{array}{l}\text { Max. tem- } \\
\text { perature on } \\
\text { surface }\end{array}$ & $\begin{array}{l}538^{\circ} \mathrm{C} \text { at } 3 \mathrm{~m} \text { height } \\
\text { or in cavities; } 260^{\circ} \mathrm{C} \\
\text { on the } 2 \text { nd storey }\end{array}$ & Not specified & Approx. $415^{\circ} \mathrm{C}$ & Not specified \\
\hline $\begin{array}{l}\text { Test } \\
\text { duration }\end{array}$ & $30+10 \min$ & $20 \mathrm{~min}$ & $25 \mathrm{~min}$ & Min. 15 min \\
\hline $\begin{array}{l}\text { Test } \\
\text { specimen }\end{array}$ & $\begin{array}{l}\text { Flat wall } 4.1 \mathrm{~m} \times \\
5.3 \mathrm{~m}\end{array}$ & $\begin{array}{l}\text { Flat wall } 1.2 \mathrm{~m} \times \\
2.4 \mathrm{~m}\end{array}$ & Flat wall $10 \mathrm{~m}$ high & $\begin{array}{l}\text { Flat wall } \mathrm{min} .2 .8 \mathrm{~m} \times \\
2.8 \mathrm{~m}\end{array}$ \\
\hline Substrate & $\begin{array}{l}150 \mathrm{~mm} \text { th. concrete } \\
\text { wall }\end{array}$ & Steel tube & Concrete & None \\
\hline Criteria $^{a}$ & $\begin{array}{l}\text { Flame spread, cavity } \\
\text { fire spread, temp. } \\
\text { rise }^{\mathrm{b}}\end{array}$ & Ignition & $\begin{array}{l}\text { Vertical flame } \\
\text { spread, heat flux }\end{array}$ & Integrity of top layer ${ }^{\mathrm{c}}$ \\
\hline
\end{tabular}

a) Additional criteria may be contained in other standards or regulations.

b) Temperature rise, vertical and horizontal flame spread on or within the wall.

c) Protection of foam plastics on external facade - protective layer must remain in place, no openings developed, does not disintegrate. S1 14 is additional non-combustibility requirement. 


\section{MATEC Web of Conferences}

\section{References}

[1] Smolka, M. et al., "Semi-natural test methods to evaluate fire safety of wall claddings", Proceedings of the $1^{\text {st }}$ International Seminar on Fire Safety of Facades, Paris, France, 14-15 November, 2013.

[2] Principles of the assessment procedure, the experimental procedure and the evaluation of tests to prove the suitability of fire protection measures against a fire exposure from outside a building close to the facade ('base fire exposure') for ETICS with polystyrene insulation - Revision 2 by DIBt internal issue 01/30/2015.

[3] DIN E 4102-20 (draft) Brandverhalten von Baustoffen und Bauteilen, Teil 20: Besonderer Nachweis für das Brandverhalten von Außenwandbekleidungen. DIN 2009.

[4] JIS A 1310 Test method for fire propagation over building façades. Japanese Standards Association, 2015.

[5] Nishio, M. et al., "Experimental study on fire propagation over combustible exterior facades in Japan", Proceedings of the $1^{\text {st }}$ International Seminar on Fire Safety of Facades, Paris, France, 14-15 November, 2013.

[6] ISO 13785-1 Reaction-to-fire tests for façades -Part 2: Intermediate-scale test. ISO, 2002.

[7] ISO 13785-2 Reaction-to-fire tests for façades -Part 2: Large-scale test. ISO, 2002.

[8] Internal Form 281. Ministry of Interior, Department of National Fire Corps, Public and Civil Defense, General Directorate for Prevention and Technical Safety, Italy, 2015.

[9] Technical Report TR073 (draft). Large Scale Fire Performance Testing of External Wall Cladding Systems. EOTA PT4 Task Group, 2013.

[10] BS 8414-1 Fire performance of external cladding systems. Test methods for non-loadbearing external cladding systems applied to the face of a building. BSI, 2002ISO 9705 Fire TestsFull-scale Room Test for Surface Products. ISO, 1993.

[11] Jensen, G., "Fire spread modes and performance of fire stops in vented façade constructions overview and standardization of test methods", Proceedings of the $1^{\text {st }}$ International Seminar on Fire Safety of Facades, Paris, France, 14-15 November, 2013.

[12] prEN 1364-6 (draft). Fire resistance tests for non-loadbearing elements - Part 6: Cavity Barriers. CEN, 2015.

[13] Yoshioka H. et al., "Large-scale Facade Fire Tests Conducted Based on ISO 13785-2 with Noncombustible Facade Specimens", Fire Science and Technology, 31, No.1, 2012.

[14] Yong-Ho Yoo et al., "Study on Prevention of Spread of Vertical Fire along Finishing Materials for External Wall of High-Rise Buildings", Proceedings of the 1st International Seminar on Fire Safety of Facades, Paris, France, 14-15 November, 2013.

[15] NFPA 285. Standard Fire Test Method for Evaluation of Fire Propagation Characteristics of Exterior Non-Load-Bearing Wall Assemblies Containing Combustible Components. NFPA, 2012.

[16] LEPIR II Test. Large scale Fire Performance testing of construction systems for façade CECMI (French committee for the evaluation and the classification of products and elements of construction as regards to fire hazard - under the French Ministry of Internal Affairs directives), 2013.

[17] MSZ 14800-6 Fire resistance tests. Part 6: Fire propagation test for building facades. Hungarian standardisation institute 2009.

[18] SP FIRE 105. Issue 5. Large scale testing of facade systems. SP Boras Sweden, 1994.

[19] Önorm B 3800-5 (draft) Fire behaviour of building materials and components - Part 5: Fire behaviour of facades - Requirements, tests and evaluations. Austrian Standards Institute, 2003.

[20] GOST 31251-2008. Facades of buildings. Fire hazard test method. Interstate council for standardisation, metrology and certification 2010. 
$2^{\text {nd }}$ International Seminar for Fire Safety of Facades, Lund (Sweden), 2016

[21] NFPA 268. Standard Test Method for Determining Ignitibility of Exterior Wall Assemblies Using a Radiant Heat Energy Source. NFPA, 2012.

[22] CAN/ULC-S134. Standard Method of Fire Test of Exterior Wall Assemblies. Underwriters Laboratories of Canada, 2013.

[23] CAN/ULC-S101 Standard Methods of Fire Endurance Tests of Building Construction and Materials. Underwriters Laboratories of Canada, 2007.

[24] CAN/ULC-S114. Standard Method of Test for Determination of Non-Combustibility in Building Materials. Underwriters Laboratories of Canada, 2005. 